\section{TISSUE OXYGEN LEVEL IN ACUTE AND CHRONIC WOUND: A COMPARISON STUDY}

\author{
Sheena P. Philimon, Audrey K. C. Huong*, Xavier T. I. Ngu \\ Faculty of Electrical and Electronic Engineering, Universiti Tun Hussein \\ Onn Malaysia, 86400 Batu Pahat, Johor, Malaysia
}

Article history

Received

21 November 2019

Received in revised form

31 May 2020

Accepted

10 June 2020

Published online

22 June 2020

\section{*Corresponding author audrey@uthm.edu.my}

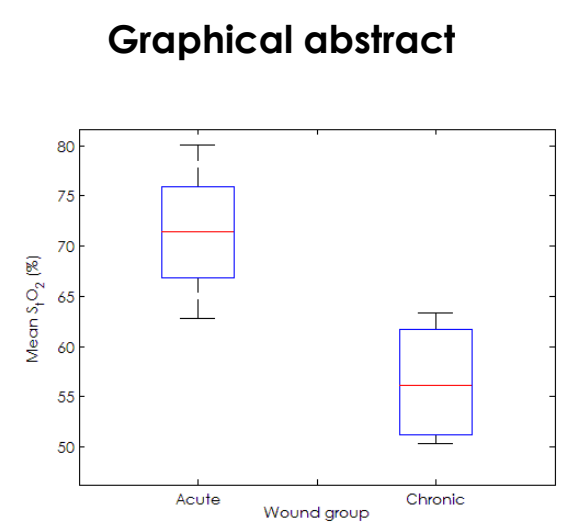

\begin{abstract}
Adequate oxygen supply to granulating tissue and its surroundings is considered as an elementary factor to render an optimum condition for proper wound healing. This paper focused on comparing the quantitative mean of transcutaneous oxygen saturation $\left(\mathrm{S}_{+} \mathrm{O}_{2}\right)$ between acute superficial wounds and chronic diabetic wounds in a randomized clinical study. A multispectral imaging system was employed for in-vivo measurement of wound $\mathrm{S}_{+} \mathrm{O}_{2}$ across a visible wavelength range of $530-570 \mathrm{~nm}$ Processed $\mathrm{S}_{+} \mathrm{O}_{2}$ maps of wounds using a reconstructed mathematical model revealed a mean $\mathrm{S}_{+} \mathrm{O}_{2}$ of $71.38 \pm 7.07 \%$ and $56.48 \pm 6.27 \%$, respectively, in acute and chronic wounds. The statistical test on the difference in the values between these two groups of wounds was shown to be statistically significant ( $\rho \leq 0.05$ ). These crucial findings contribute to the existing knowledge on the $\mathrm{S}_{+} \mathrm{O}_{2}$ range and its variation in different wound conditions. In conclusion, the proposed multispectral imaging system is able to produce clinical information of wound oxygenation level for a better understanding of the obligatory role of oxygen as a key determinant in healing outcomes.
\end{abstract}

Keywords: Acute wound, chronic wound, multispectral imaging, tissue oxygenation, Extended Modified Lambert-Beer model

\begin{abstract}
Abstrak
Bekalan oksigen yang mencukupi untuk granulasi tisu dan persekitarannya dianggap sebagai faktor asas untuk menjamin keadaan yang optimum bagi penyembuhan luka yang wajar. Kertas kerja ini membandingkan min kuantitatif ketepuan oksigen transkutan $\left(\mathrm{S}_{+} \mathrm{O}_{2}\right)$ antara luka akut superfisial dan luka kronik diabetik dalam kajian klinikal rawak. Sistem pengimejan multispektral tidak invasif digunakan untuk pengukuran in-vivo $\mathrm{S}_{+} \mathrm{O}_{2}$ luka merentasi panjang gelombang nampak $530-570 \mathrm{~nm}$. Peta $\mathrm{S}_{\uparrow} \mathrm{O}_{2}$ data multispektral yang diproses menggunakan model matematik yang dibina semula mendedahkan min $\mathrm{S}_{\uparrow} \mathrm{O}_{2}$ pada $71.38 \pm 7.07 \%$ dan $56.48 \pm 6.27 \%$, masing masing, dalam luka akut dan kronik. Ujian statistik perbezaan nilai antara dua kumpulan luka ini menunjukkan keertian statistik $(\rho \leq 0.05)$. Penemuan penting ini menyumbang kepada pengetahuan sedia ada mengenai julat dan variasi $\mathrm{S}_{\uparrow} \mathrm{O}_{2}$ dalam keadaan luka yang berbeza. Kesimpulannya, sistem pengimejan multispektral yang dicadangkan dapat menghasilkan maklumat klinikal tahap oksigenasi luka untuk memahami peranan wajib oksigen sebagai penentu utama dalam hasil penyembuhan.
\end{abstract}

Kata kunci: Luka akut, Luka kronik, pengoksidaan tisu, model Extended Modified Lambert-Beer

(C) 2020 Penerbit UTM Press. All rights reserved 


\subsection{INTRODUCTION}

A wound is caused by injury inflicted on the skin barrier resulting in a disruption of the anatomic structure and functionality of the skin tissue. A general categorization of wound is usually divided into either acute or chronic wounds. This is based on several aspects such as the distinct appearance and severity of wound, and the recovery rate of wounded tissues in which the anatomical structure is eventually restored. An acute wound is normally caused by an injury or abrasion that affects the superficial surface of the skin. Contrary to this, the cause of a chronic wound is due to its more complex pathophysiology with an unpredictable healing rate. Diabetic ulcer, a common example of chronic wound, can take months, or even years, to establish full recovery of its anatomic and functional integrity due to poor oxygenation in the wound [1]. Following this, healed wounds can be further categorized as minimally, acceptably or ideally healed to be used as a reference for post-treatment as discussed in Lazarus et al. [2].

Prior knowledge on the different stages of wound healing progression is vital to identify appropriate markers and indicators as guidelines for proper clinical diagnosis and therapy. Assessment of wound includes a complete understanding of wound pathophysiology, different environmental factors that affect healing and in-depth knowledge of tissue remodeling $[3,4]$. Wound healing is a multifaceted process concerning skin physiological properties. The wound healing stages can be divided into three main stages, i.e. inflammatory, proliferation which involved neoangiogenesis, and tissue reepithelialization or remodeling stage $[5,6]$. These various stages and sequence of wound healing are overlapping processes that occur concurrently within a specific time length immediately after the disruption of skin barrier following an injury. Each stage involved is a highly oxygen-dependent process that stimulates the production of reactive oxygen species (ROS); the latter is known for its main role in bacterial defense. The role of oxygen is often highlighted in wound management, wherein state of tissue oxygenation is used as an indicator of wound healing progression. A general perception of wound oxygenation is that adequate supply of oxygen is vital for optimal healing $[7,8]$.

A major concern, however, is the lack of oxygen during healing due to a lower tissue partial pressure of oxygen $\left(\rho_{2}\right)$ as compared to $\rho_{2} \mathrm{O}_{2}$ under basal condition [9]. Increasing demand for oxygen supply normally occurs during angiogenesis. The influence of low oxygen pressure can subsequently hinder wound healing in a manner that can possibly damage the surrounding tissues and cells. In particular, lack of oxygen supply is one of the core factors affecting the deposition of collagen due to the reason that angiogenesis process is proportional to $\mathrm{OO}_{2}$ in wounded tissue. To overcome this matter, hyperbaric oxygen therapy is often recommended for correction of wound $\mathrm{\rho O}_{2}$ to improve perfusion that is required for rapid healing [10]. Other clinical alternative options include the use of hemoglobin spray solution to promote wound healing [11]. To this end, different technologies have emerged in recent years to measure wound tissue oxygen levels and to predict tissue repair activities $[12,13]$. These include the use of hyperspectral imaging system [14], photoacoustic imaging [15], multimodal medical imaging [16] and Frequency Domain diffuse spectroscopy system [17]. While these strategies are able to reveal observable changes in oxygen level with different stages of healing, such equipment is complex and costly. In addition to this, other researchers have also proposed an alternative method using near-infrared (NIR) spectroscopy for early detection of critical glucose level among diabetic patients [18]. Meanwhile multispectral imaging, which is a simpler version of a hyperspectral imaging modality, has raised an increasing interest especially in the study of wound healing. This technique is unique as it is able to detect light intensity across spatial and spectrum directions without suffering from complexity, cost and computational burden of its hyperspectral counterpart, and its application not being restricted to a small region of a measurement subject. Huong et al. [19] have recently demonstrated the most probable range of tissue oxygen levels in wounds that healed timely using multispectral imaging system that provide illumination across a visible wavelength range of $520-600 \mathrm{~nm}$.

This study aims to expand the previous study in [20] by investigating and comparing the distribution of $\mathrm{S}_{+} \mathrm{O}_{2}$ levels in acute wounds of healthy subjects and chronic wounds of diabetic subjects. An improved use of multispectral imaging system is introduced in this study by employing an alternative shorter wavelength range of $530-570 \mathrm{~nm}$ to detect reflectance data from the wound surface. This study compares, statistically analyzes and reports $\mathrm{S}_{+} \mathrm{O}_{2}$ values in both acute and chronic wounds.

\subsection{METHODOLOGY}

\subsection{Multispectral Imaging System}

A schematic arrangement of the experimental setup and instruments employed in this study is shown in Figure 1. The laboratory assembled multispectral imaging system comprised of a high-intensity white light-emitting diode (XLamp® XQ-E LED from Cree) as the light source while a charge-coupled device (CCD) (BUC4-500C from BestScope) was employed as its light detector. In this study, light in the visible wavelength range of $530-570 \mathrm{~nm}$ with sampling size of $10 \mathrm{~nm}$ was tuned using a commercially available monochromator (Oriel Mini Monochromator part no. 78026 from Newport) with a built-in diffraction grating to illuminate the wounded skin. The experiment was 
designed to be performed in reflection mode, thus, the monochromatic system was placed at an angle of approximately $45^{\circ}$ from normal to reduce glare. A plano-convex lens with diameter, $\varnothing=12.77 \mathrm{~mm}$, and focal length of $50.22 \mathrm{~mm}$ were placed at normal from the skin surface in front of the imager. This optical lens was used to focus light reflected from the targeted site onto the $1920 \times 2576$ pixels highresolution CCD with a pixel size of $3.4 \mu \mathrm{m} \times 3.4 \mu \mathrm{m}$. The integration time of the CCD was set to 10 seconds to increase the signal-to-noise performance.

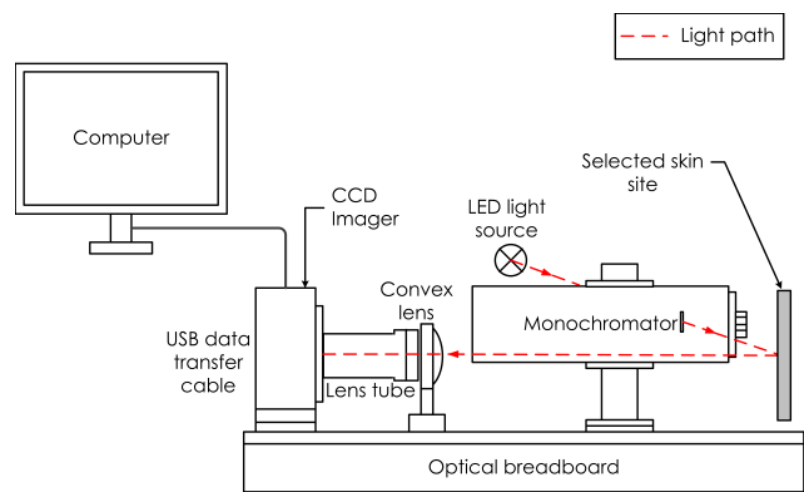

Figure 1 Schematic arrangement of multispectral imaging system for non-invasive investigation of wound $\mathrm{S}_{+} \mathrm{O}_{2}$

The distance between the skin site and CCD shown in Figure 1 was given by $170 \mathrm{~mm}$ and $200 \mathrm{~mm}$, respectively, for measurement on acute and chronic wounds. These different experimental arrangements were made based on the position of the wound and for the convenience of the patients. It was reported in Philimon et al. [20] that changes in the separation of skin region-detection system yielded different $\mathrm{S}_{+} \mathrm{O}_{2}$ values. Since this experiment involved processing the spatially dependent reflected intensity of the multispectral images, a calibration procedure was necessary to normalize the measured reflectance from both samples. The relationship between spatial separation and $\mathrm{S}_{+} \mathrm{O}_{2}$ at five varying distances (i.e. 30 $\mathrm{mm}, 50 \mathrm{~mm}, 100 \mathrm{~mm}, 150 \mathrm{~mm}$ and $200 \mathrm{~mm}$ ) was previously reported in [20]; the recorded results and the corresponding fitted linear line is shown in Figure 2. Based on the best fitted line in Figure 2, a normalization factor of 1.08 was calculated from the ratio of the value at $170 \mathrm{~mm}$ and $200 \mathrm{~mm}$. Using the $170 \mathrm{~mm}$ arrangement as the standard, this factor was applied to the $\mathrm{S}_{+} \mathrm{O}_{2}$ map of chronic wounds.

\subsection{Experimental Subjects and Procedure}

In this case study, eight Asian subjects aged between 19 - 64 years old, with a mean \pm standard deviation age of $37.75 \pm 19.26$ years, consisting of both male and female with newly developed or ongoing wounds at different parts of the body were recruited for investigation of wound tissue oxygenation. These subjects were generally categorized into two major groups, namely subjects with acute superficial cutaneous wounds and subjects with chronic diabetic wounds. Subjects with acute wounds were recruited from the University Health Center, Universiti Tun Hussein Onn Malaysia (UTHM). These subjects were healthy during the participation in this study, they have declared no any underlying illnesses prior to the experiment. Meanwhile subjects with chronic wounds were mainly Type 2 diabetic patients presented with foot ulcer recruited from the outpatient clinic at the Orthopedic Department, Hospital Sultanah Nora Ismail, Batu Pahat.

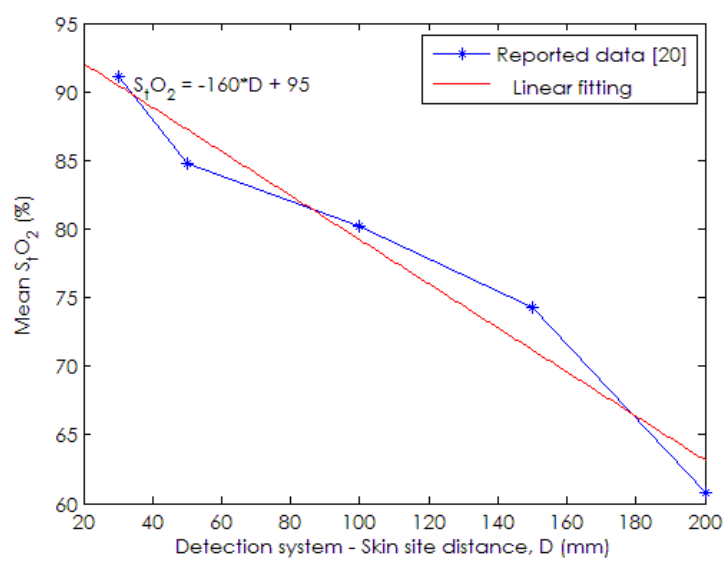

Figure 2 Spatial distance-dependent $\mathrm{S}_{+} \mathrm{O}_{2}$ reported in [20] and linear fitted curve

This study was reviewed and approved by the Medical Research and Ethics Committee (MREC), Ministry of Health Malaysia (MREC reference number KKM/NIHSEC/P17-145 / NMRR-16-2475-33611) and Human Research Ethics Committee in UTHM (ref no. UTHM/RMC.100-9/39(22)). The participation was voluntary whereby corresponding subjects were asked to fill out an informed consent prior to the experiment. Exclusion criteria include pregnant subjects and those with a past medical history of hypertension, cardiac disease, vascular disorder, respiratory disorder, severe anemia (hemoglobin $\leq 7 \mathrm{~g} / \mathrm{dL}$ ) or any diseases that might affect the blood oxygen saturation reading. The work carried out in this study is non-invasive and merely an observational study so no treatment or drug was administered to patients.

Prior to the experiment, the wound condition was first examined by medical professionals to confirm the cessation of bleeding. Measurement was performed after the wound had been cleansed but prior to wound dressing change. Reflectance spectroscopy was measured from the examined wound placed inside an enclosed makeshift cubicle under total darkness to eliminate the interference of stray light. The wounded body part was placed on foam support for increased stability and to reduce motion artefacts during measurement. Each subject 
was first acclimatized to a controlled room temperature set at $20{ }^{\circ} \mathrm{C}$ for at least 15 minutes prior to measurement. Throughout the experimental process, all other illuminating light sources inside the cubicle was blocked out with a black matte cloth draped over the entrance slot except for the monochromatic source, which was tuned one at a time.

\subsection{Image Processing and Analysis}

The prediction of the required $\mathrm{S}_{+} \mathrm{O}_{2}$ value based on the collected multispectral images is via a modelfitting approach. This work used Extended Modified Lambert-Beer (EMLB) model for the estimation of $\mathrm{S}_{+} \mathrm{O}_{2}$. This analytic model was designed based on a priori knowledge of different types of absorbing constituents present in the skin epidermal and dermal layers [21]. The EMLB model in Equation (1) is an extension of Modified Lambert-Beer (MLB) law complemented by an exponential function for improved representation of light propagation behavior in a turbid medium, which is taken as a complex function of dermal light absorption and scattering.

$$
A(\lambda)=G_{0}+\mu_{a} d_{0}+G_{1} \lambda+\lambda \exp \left(-\mu_{a} d_{1}\right) .
$$

Light attenuation offset is represented by parameter $G_{0}$ while parameters $\mu_{a}$ and $d_{0}$ denote light absorption and "light pathlength", respectively. Since both light scattering and absorption in skin epidermal decrease approximately linearly with wavelength, $\lambda$, this equation assumes a linear wavelength dependent light attenuation due to scattering and absorption in the medium, represented by $G_{1} \lambda$. Meanwhile the exponential term in Equation (1) is to represent the complex function of light attenuation with dermal light scattering-absorption, which is theoretically known to yield changes in "light pathlength", $d_{1}$, in the dermis.

Expressing light attenuation, $A(\lambda)$, as a function of $\mathrm{S}_{4} \mathrm{O}_{2}$ and blood oxyhemoglobin $\left(\mathrm{HbO}_{2}\right)$ and deoxyhemoglobin $(\mathrm{Hb})$ gives the complete model shown in Equation (2). The value of total hemoglobin concentration, $T$, is taken here as $1 \mathrm{M}$ for the ease of analysis.

$$
A(\lambda)=G_{0}+\left(\Delta \varepsilon S_{\dagger} O_{2}+\varepsilon_{\text {Hb }}(\lambda)\right) d_{0} T+G_{1} \lambda+\lambda \exp \left(-\left(\Delta \varepsilon S_{\dagger} O_{2}+\varepsilon_{\text {Hb }}(\lambda)\right) d_{1} T\right) .
$$

These specific extinction coefficient values of each hemoglobin component, $\varepsilon$, are from the report of Zijlstra et al. [22]. The $\Delta \varepsilon$ in Equation (2) represents $\varepsilon_{\mathrm{HbO}_{2}}(\lambda)-\varepsilon_{\mathrm{Hb}}(\lambda)$. This work considered data of wavelength range $530-570 \mathrm{~nm}$; this is considering the distinctive absorption of hemoglobin within this wavelength range.
Multispectral data were saved in raw format for offline processing. The $\mathrm{S}_{+} \mathrm{O}_{2}$ value was solved by means of an iterative fitting of the measured attenuation data using the model in Equation (2). The steps involved in seeking the optimal value of the unknown parameters using the MATLAB function fminsearch (MathWorks Inc.) are summarized in Figure 3.

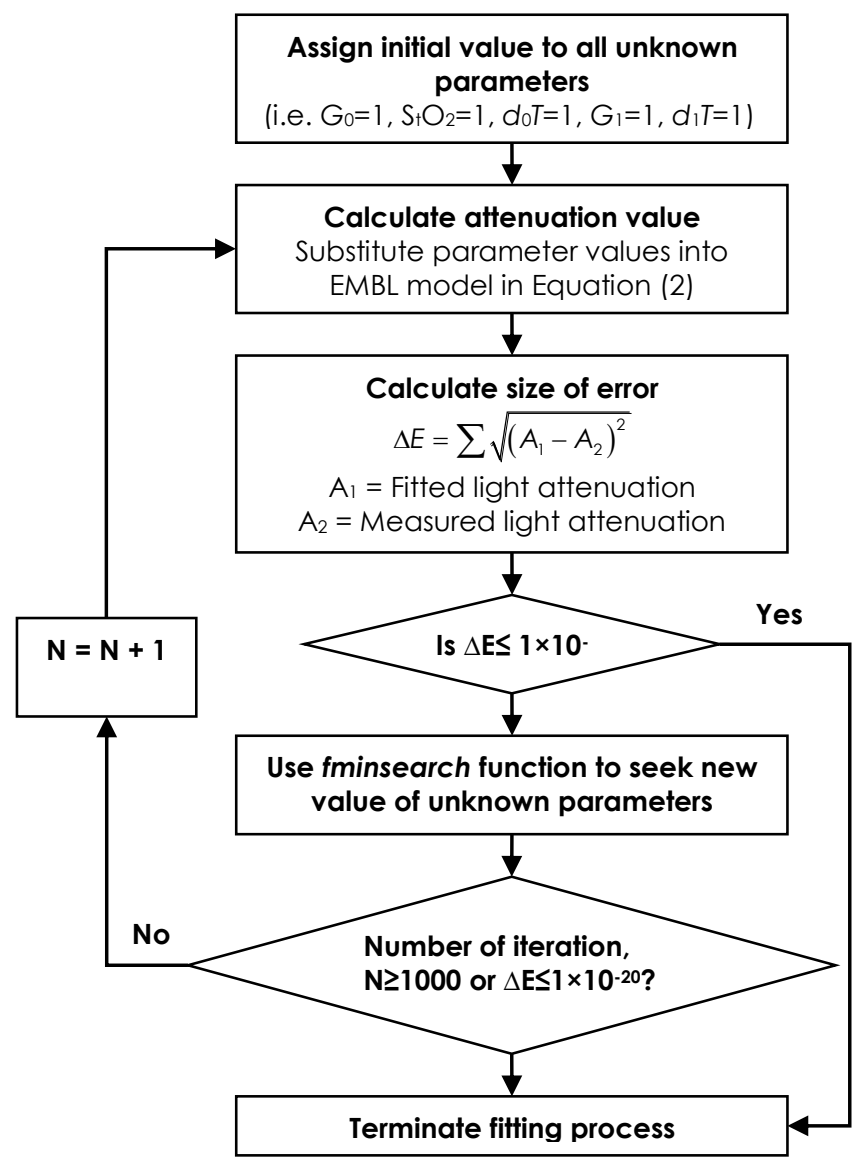

Figure 3 Unconstrained iterative fitting procedure to seek for the optimal $\mathrm{S}_{+} \mathrm{O}_{2}$ value

This fminsearch fitting function applies an unconstrained non-linear optimization routine to iteratively seek the new value of the fitting parameters based on the size of error between the value from the analytical model and the measured attenuation, $\Delta E$. The fitting process is terminated when either the absolute mean $\Delta E$ is less than $1 \times 10^{-20}$ or the number of iteration has achieved 1000 when an optimum $\mathrm{S}_{+} \mathrm{O}_{2}$ value is assumed to have been obtained. Averaging of pixels using an array size $10 \times 10$ was performed to reduce inconsistency between neighboring pixels. 


\subsection{RESULTS AND DISCUSSION}

The processed $\mathrm{S}_{+} \mathrm{O}_{2}$ maps of the investigated wound regions of dimension size of $15 \mathrm{~mm} \times 20 \mathrm{~mm}$ (acute wound) and $5 \mathrm{~mm} \times 7 \mathrm{~mm}$ (chronic wound) are illustrated in Figure 5 and Figure 6, respectively. The selected wound region of interest is marked by the black dashed box. Wounds (a)-(d) in Figure 5 are categorized as acute superficial wound and wounds (e)-(h) in Figure 6 are categorized as chronic diabetic wound. The percent wound tissue oxygenation value is indicated by a color bar positioned on the right of the $\mathrm{S}_{+} \mathrm{O}_{2}$ map while the respective wound image is shown on the top of the map. The closer the pixels color to the higher end of the color bar is corresponded to the high tissue oxygenation level in the wound bed. As expected, an overall higher mean percent $\mathrm{S}_{+} \mathrm{O}_{2}$ was observed in acute wounds as compared to that of chronic wounds. The mean and standard deviation of the $\mathrm{S}_{+} \mathrm{O}_{2}$ calculated from these maps are tabulated in Table 1. The separation of skin region-detection system, specifically referring to the distance between the skin site and CCD camera, is bound to yield changes in spatial resolution of the processed $\mathrm{S}_{+} \mathrm{O}_{2}$ maps. The findings from this study have shown that a shorter spatial distance of $170 \mathrm{~mm}$ would produce a higher calculated percent $\mathrm{S}_{+} \mathrm{O}_{2}$ value as compared to that measured at $200 \mathrm{~mm}$. Considering both acute and chronic wounds were measured at different distances as discussed in section 2.1, the $\mathrm{S}_{+} \mathrm{O}_{2}$ values of chronic wounds are normalized using a factor of 1.08 to give its equivalent values at $170 \mathrm{~mm}$; this is to allow a direct and comparable comparison with the data of acute wounds. The $\mathrm{S}_{+} \mathrm{O}_{2}$ values for chronic wounds before and after normalization are presented in Table 1.

In the subsequent text, all the $\mathrm{S}_{+} \mathrm{O}_{2}$ presented for chronic wounds are of the normalized value as shown in Table 1. The values between the mean $\mathrm{S}_{+} \mathrm{O}_{2}$ of acute and chronic wounds in Table 1 were statistically analyzed using a two-tailed independent samples t-test in SPSS software (IBM SPSS Statistics,
Version 23). The result revealed a statistically significant difference of $\rho \leq 0.05$ at $95 \%$ confidence interval. A higher absolute mean $\mathrm{S}_{+} \mathrm{O}_{2}$ value of $71.38 \pm 7.07 \%$ calculated for wounds (a)-(d) in Table 1 is recorded for the acute wound group and a lower mean $\mathrm{S}_{+} \mathrm{O}_{2}$ value of $56.48 \pm 6.27 \%$ from wounds (e)-(h) is observed for the chronic wound group. The median $\mathrm{S}_{+} \mathrm{O}_{2}$ values of acute and chronic wounds are given by $71.38 \%$ and $56.11 \%$, respectively. A box plot comparing $\mathrm{S}_{+} \mathrm{O}_{2}$ data for the acute and chronic wound subjects are shown in Figure 4.

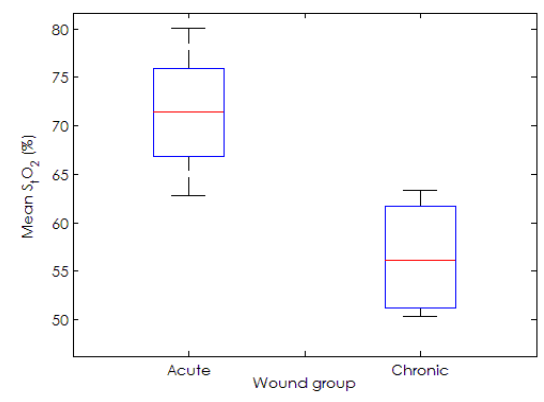

Figure 4 The percent mean $\mathrm{S}_{+} \mathrm{O}_{2}$ estimated for the acute (left) and chronic (right) wound subjects. The median value of the respective data sets are indicated by the red line in the center of the box plot

These results highlight the differences in tissue oxygenation level of wounds during healing; specifically, the $\mathrm{S}_{\mathrm{H}} \mathrm{O}_{2}$ values in acute wounds are considerably higher than that observed in chronic wounds. Comparing the results of $\mathrm{S}_{+} \mathrm{O}_{2}$ measured from the clinical study, it was obvious that the $\mathrm{S}_{+} \mathrm{O}_{2}$ levels, whilst least affected by gender and age, are highly dependent on individual's health and physical condition. Generally, a rise in tissue oxygenation level was expected following injury. This was observed among subjects with acute wounds, of which a mean $\mathrm{S}_{+} \mathrm{O}_{2}$ in the range of $60 \%-80 \%$ was observed during healing.

Table 1 Mean and standard deviation (SD) of $\mathrm{S}_{+} \mathrm{O}_{2}$ of acute wounds (subjects (a)-(d)) and chronic wounds (subjects (e)-(h)) calculated from the $\mathrm{S}_{+} \mathrm{O}_{2}$ maps in Figure 5 and Figure 6

\begin{tabular}{clcc}
\hline Wound & \multicolumn{1}{c}{ Wound site } & $\begin{array}{c}\text { Mean } \pm \text { SD of percent } \mathbf{S}_{\mathbf{H}} \mathbf{O}_{2} \\
\text { (chronic wounds at 200 } \mathbf{~ m m} \text { ) }\end{array}$ & Mean \pm SD of percent $\mathbf{S}_{+} \mathbf{O}_{2}$ \\
\hline (a) & Plantar fascia of foot & - & $70.95 \pm 2.93 \%$ \\
(b) & Thenar of palm & - & $62.74 \pm 1.00 \%$ \\
(c) & Lateral posterior forearm & - & $71.80 \pm 2.25 \%$ \\
(d) & Nail bed of toe & $58.76 \pm 0.79 \%$ & $80.03 \pm 3.22 \%$ \\
(e) & Plantar fascia of foot & $55.66 \pm 2.67 \%$ & $* 52.11 \pm 6.63 \%$ \\
(f) & Plantar fascia of foot & $46.59 \pm 3.04 \%$ & $* 60.11 \pm 2.89 \%$ \\
(g) & Dorsal fascia of foot & $58.68 \pm 1.48 \%$ & $* 50.32 \pm 3.28 \%$ \\
(h) & Phalanx of toe & & $* 63.38 \pm 1.60 \%$ \\
\hline
\end{tabular}

*normalized result following discussion in section 2.0 
An explanation for this occurrence could be attributed to the production of ROS to promote angiogenesis and homeostasis of tissue vasculature. Disruption of cell structure in wounded tissue would result in an increase of oxygen consumption in the immune system, hence, stimulating nicotinamide adenine dinucleotide phosphate (NADPH) oxidase that generates metabolites [23]. In a related study from this laboratory, wound bed was found to have high $\mathrm{S}_{+} \mathrm{O}_{2}$ which deprived the surrounding tissue of oxygen [19]. The $\mathrm{S}_{\mathrm{H}} \mathrm{O}_{2}$ level in wound gradually decreases as the wound enters maturation phase, denoting a stabilized immune system and regulated oxygen consumption. This indicates the wound is reepithelialized, collagen fibers are reorganized, and the tissue structure is remodeled to achieve full functionality of the skin structure.

Meanwhile, a reduced mean $\mathrm{S}_{+} \mathrm{O}_{2}$, i.e. $14.90 \%$ lower than the calculated mean $\mathrm{S}_{1} \mathrm{O}_{2}$ of acute wound was observed among subjects with chronic diabetic wounds. Contrary to the previous explanation on the role oxygen as one of the vital mechanisms necessary to speed up the healing process which resulted in immediate rise in $\mathrm{S}_{+} \mathrm{O}_{2}$ level, a notably lower mean $\mathrm{S}_{+} \mathrm{O}_{2}$ value was observed in subjects with chronic wounds. The measured $\mathrm{S}_{+} \mathrm{O}_{2}$ values of diabetic subjects reflected the poor blood perfusion as a major impediment to reduced tissue oxygenation, this often associated with thickening of the capillary wall and fibrin deposition in addition to reduced arterial blood flow in peripheral arterial and vascular diseases [24]. Characteristic traits among subjects with diabetic neuropathy included blood flow impairment, thickening of the capillary basement membrane and hypoxia due to capillary blockage. Wound hypoxia in DFU is mainly due to increased demand for oxygen in severe ulcers as well as microvascular (e.g. capillary) and microvascular (e.g. vein and artery) complications [25]. Other factors may include sedentary lifestyle and poor wound management; the compound of all these factors renders wound ischemia $[26,27]$.

Post wounding study had shown a longer time taken for chronic wounds to heal. A comprehensive visual inspection of the physical conditions of chronic wounds showed no evident reduction in wound perimeter despite advanced wound dressings to improve wound perfusion and intravenous insulin prescription to control glucose level. Unlike acute wounds that healed within a timely period of fewer than two months, the chronic wound depicted an unpredictable healing trend that extended to a period no less than six months. This study had also observed chronic wounds that revealed no progressive healing due to extreme hypoxia which eventually led to cellular demise and amputation of the affected body part (subjects (f), (g) and (h)).

From the results presented in Table 1, the standard deviation of $\mathrm{S}_{+} \mathrm{O}_{2}$ in chronic wounds ranged between $\pm 1.60 \%- \pm 6.63 \%$, which is slightly higher than those measured from acute wounds
$( \pm 1.00 \%- \pm 3.22 \%)$. A possible explanation for these mean variabilities is due the inconsistency in the spatial dependent reflectance signals collected from irregular wound surface. This irregularity manifests itself in the differences in the distribution of reflectance signals, affecting the calculated $\mathrm{S}_{+} \mathrm{O}_{2}$ maps shown in Figure 5 and Figure 6, and hence the mean percent $\mathrm{S}_{+} \mathrm{O}_{2}$ value in Table 1. Nonetheless, based on these $\mathrm{S}_{+} \mathrm{O}_{2}$ maps, one can deduce the quantitative information on tissue oxygenation level at specific wound points. In addition, a physical assessment of the condition of chronic wounds revealed presence of slough and suppurative exudate, which was confirmed by medical professionals, and these factors no doubt affected the distribution of values in the $\mathrm{S}_{+} \mathrm{O}_{2}$ maps in Figure 6. Based on the general observation of these results, regions with turquoise-yellow hue with a larger $\mathrm{S}_{+} \mathrm{O}_{2}$ range could be seen. These values corresponded to a deprive of oxygen in the wound bed, which further suggests that the decreased $\mathrm{S}_{+} \mathrm{O}_{2}$ value down to $15 \%$ compared to acute wound could be attributed to local vasoconstriction or impaired angiogenesis in wound tissue resulting in delay of chronic wound healing. Meanwhile an example of the wound shown in Figure $5(\mathrm{~b})$ revealed an isolated higher $\mathrm{S}_{+} \mathrm{O}_{2}$ value greater than $80 \%$ in the specific wound site indicated by the circle as compared to the surrounding healed site which showed a lower value of approximately $60 \%$. This process is necessary as reported in Huong et al. [19] to ensure optimal channeling of oxygen to the injured tissue for a progressive wound healing, particularly during the proliferative stage. A high $\mathrm{S}_{+} \mathrm{O}_{2}$ above $70 \%$ at the granulating tissue and a large fluctuation in this value would warrant progressive and timely healing, especially during the neoangiogenesis and reepithelialization stages, regardless of the wound condition. During this refined study, it is also important to note that the application of amorphous hydrogel wound dressing and regular therapeutic follow-up contributed to the healing process. This was sustained by the function of dressings for autolytic debridement of necrotic tissues and to promote moist surroundings, as well as to ensure elevated wound surface area reduction and a shorter healing time [28]. The results of these treatments were more evident in acute wounds as compared to chronic wounds. It is also noted that subjects with chronic wounds were prescribed with Methylcobalamin, a form of Vitamin $B$, commonly used for restoration of red blood cells in neuropathy.

From the $\mathrm{S}_{+} \mathrm{O}_{2}$ maps presented in Figure 5 and Figure 6, the results showed an overall standard deviation of $\pm 7.07 \%$ for acute wound and $\pm 6.27 \%$ for chronic wound. It must be mentioned that during the course of this study, it was impossible to replicate the exact position of investigation site due to the differences in wound locations on body. Thus, these wounds were placed according to the convenient of the subjects and optimal focal position during the experiment. 
137 Sheena P. Philimon, Audrey K. C. Huong \& Xavier T. I. Ngu / Jurnal Teknologi (Sciences \& Engineering) 82:4 (2020) 131-140
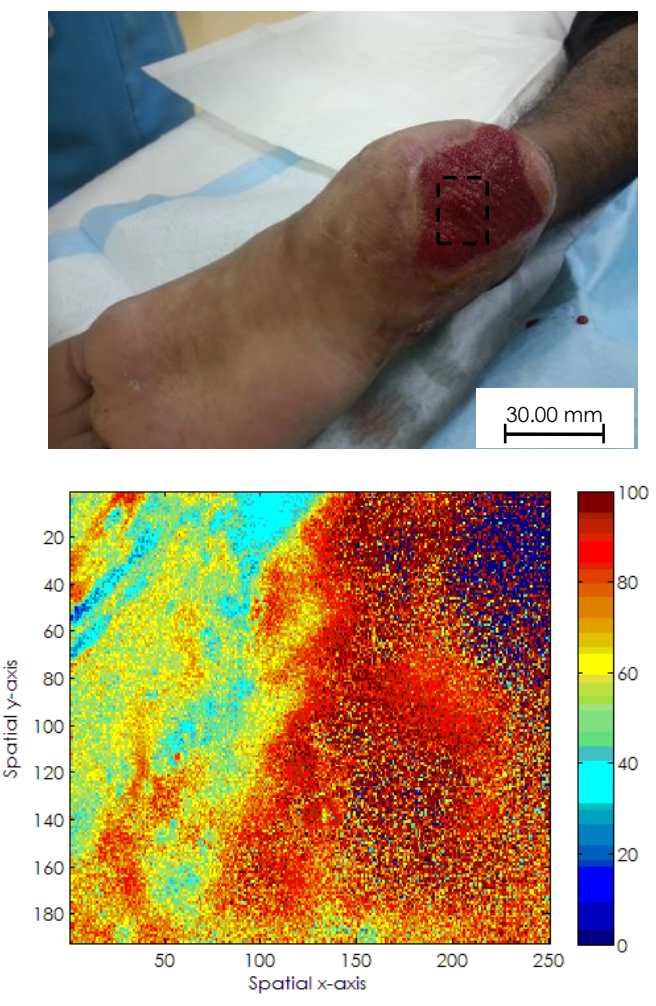

Acute wound (a)
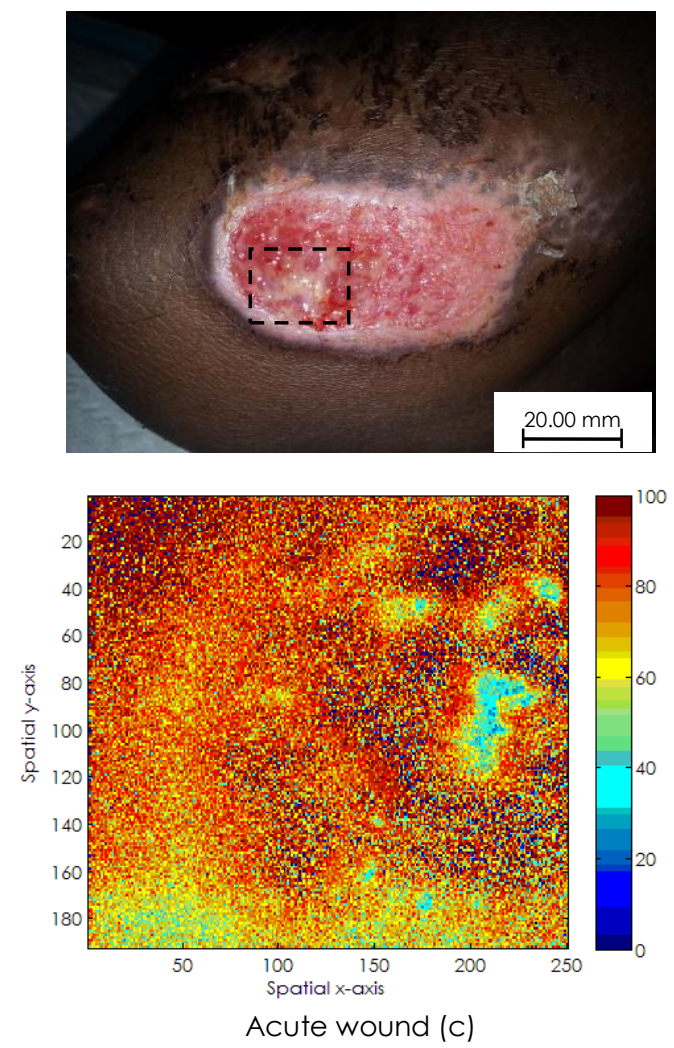
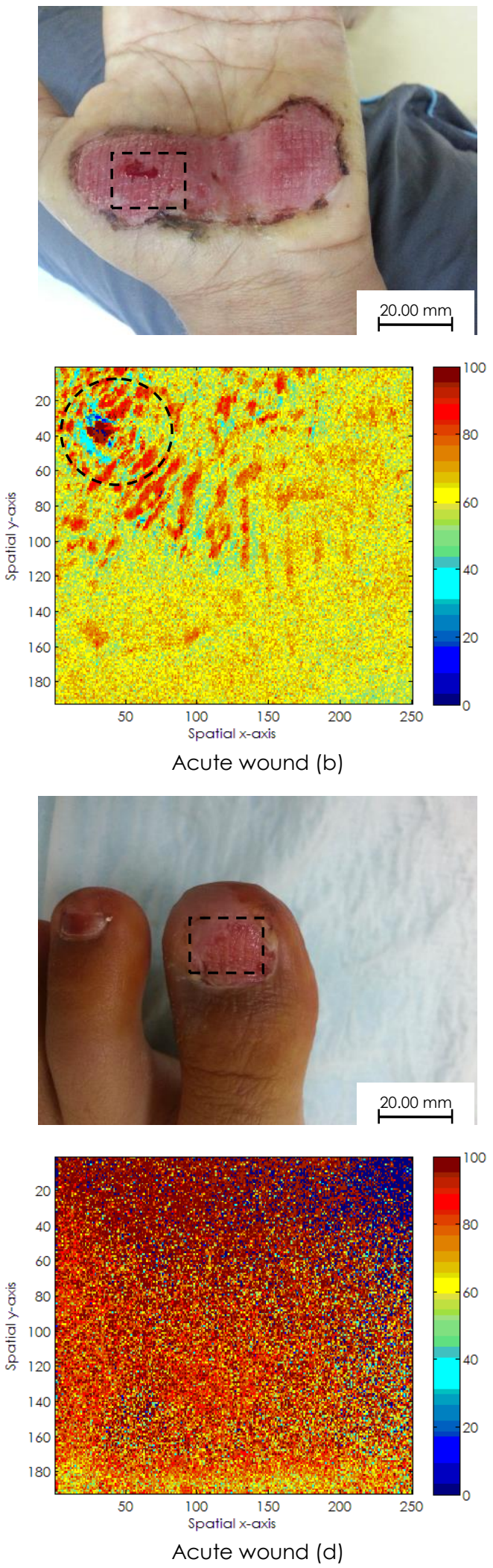

Figure 5 In-vivo multispectral imaging of acute cutaneous wound and its respective $\mathrm{S}_{+} \mathrm{O}_{2}$ map (labeled (a) to (d)) 

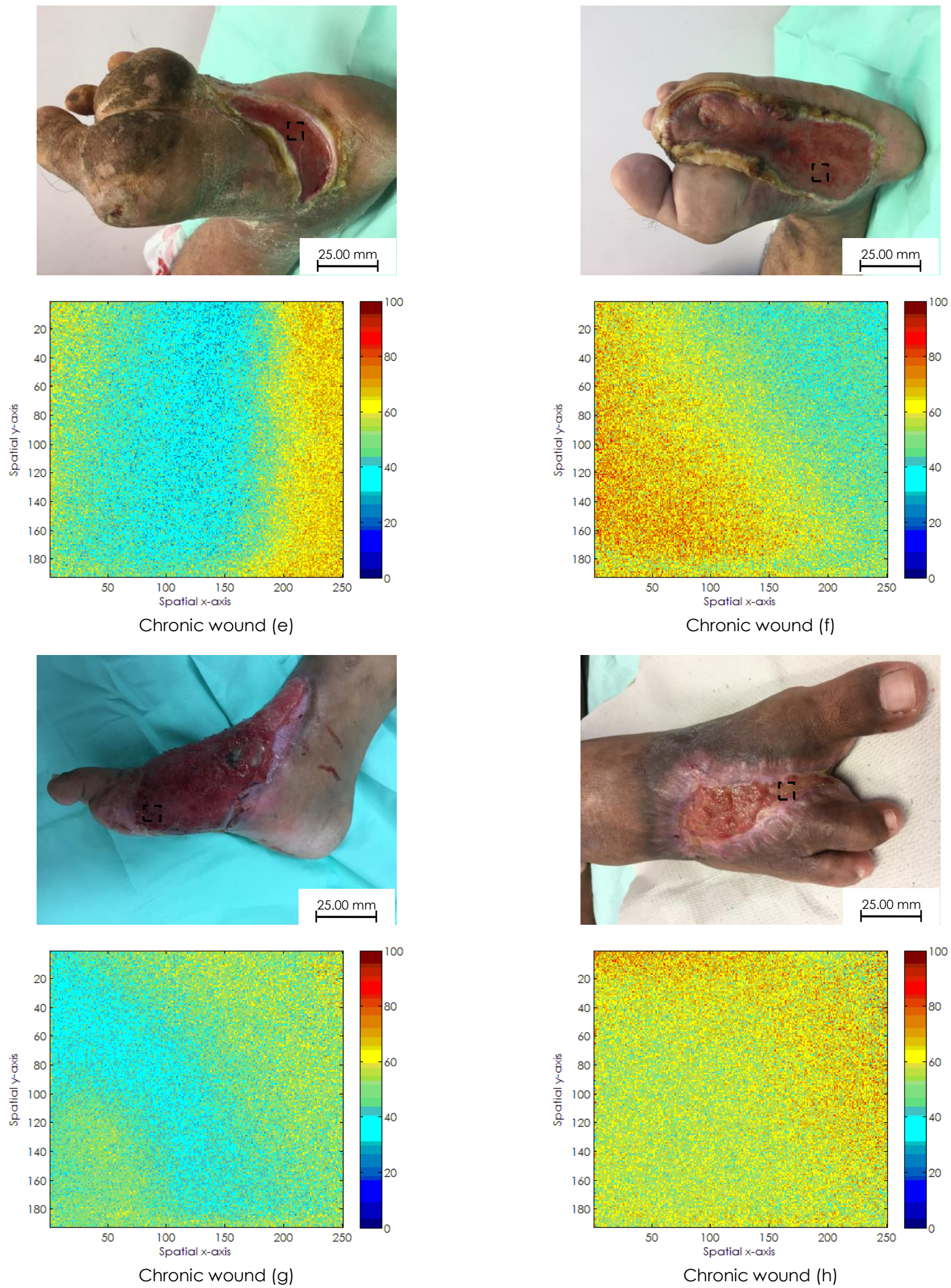

Figure 6 In-vivo multispectral imaging of chronic diabetic wound and its respective $\mathrm{S}_{+} \mathrm{O}_{2}$ map (labeled (e) to (h)) 
On this note, since measurements were performed on different body parts, in which the variation in mean $\mathrm{S}_{+} \mathrm{O}_{2}$ was considerably large [29], the results are affected by several factors such as location of blood vessels in the measured region and light penetration depth depending on the melanocytes distribution. However under theoretical circumstances, detected reflected signals are assumed to have propagated in the skin medium and carry sufficient and useful information on scattering and absorption features of the investigation site.

The multispectral imaging system introduced in this work is able to provide both visual and quantitative information of tissue oxygenation level in acute and chronic wounds. The findings from this study imply that the $\mathrm{S}_{+} \mathrm{O}_{2}$ level in chronic wounds is lower than that observed in acute wounds, which further supports the reason for the impaired healing progress often faced by patients with diabetic neuropathy. Unlike the point spectroscopy technique, this imaging technique provides larger FOV and better imaging resolution. While multiple site-measurements would be advantageous, a larger FOV would be preferable in this study, this is considering that the former would inadvertently increase the acquisition time (given the current acquisition time is around 60 seconds). Although the FOV can be widened by increasing the separation between skin site-detector, this would be at the price of reduced signal-to-noise ratio (SNR) of image. Therefore, there is a need to compromise the loss of spatial resolution by setting a FOV that produces acceptable image quality. However, one of the challenges of using a multispectral system in biomedical imaging application is the motion artefacts [30] and uneven curvature of the body which was also addressed in the works of Vogel et al. [31]. Therefore, to overcome this matter, efforts were made to ensure the multispectral images were taken from the center of the wound bed where the surface is presumably flat. This has, no doubt, limits the field of view of the imaging system. Besides this, averaging of the $\mathrm{S}_{+} \mathrm{O}_{2}$ map was explained in the methodology to reduce spatial differences in the wound images. Although the present system requires a considerable amount of time for data to be captured and subjects are required to remain still to ensure stability of the measurement, the processed $\mathrm{S}_{+} \mathrm{O}_{2}$ map provides invivo information of wound oxygenation status that allows medical physicians to decide on early clinical diagnosis in response to different medical treatments.

This study concluded that the strategies explored in this work can provide quantitative information of changes in blood oxygen with tissue revascularization, this may be of useful diagnostic tool to evaluate the outcomes of skin grafting procedures with minimal invasive surgery. Future works would suggest employing a larger variant of wound samples collection and proposing a longitudinal study for investigation of changes in wound healing parameters at various phases, namely the inflammatory, proliferative and remodeling phases.

\subsection{CONCLUSION}

This work has demonstrated the practicability of employing non-invasive reflectance spectroscopy for the prediction of wound tissue oxygenation status in acute wounds of healthy subjects and chronic wounds of DFU subjects. Processed $\mathrm{S}_{+} \mathrm{O}_{2}$ maps for recruited samples using a reconstructed mathematical model revealed a higher mean $\mathrm{S}_{+} \mathrm{O}_{2}$ of $71.38 \pm 7.07 \%$ in acute wounds, while a lower value of $56.48 \pm 6.27 \%$ in chronic wounds. An independent samples $t$-test confirmed that the mean $\mathrm{S}_{+} \mathrm{O}_{2}$ between the acute and chronic wound groups are statistically significant $(\rho \leq 0.05)$, which supports the hypothesis of this study on the differences in wound oxygen level. It can be concluded based on the obtained results that a higher $\mathrm{S}_{+} \mathrm{O}_{2}$ level is notably evident in acute wounds as compared to chronic wounds, which process is vital for production of new cells and to assist in bacterial defense for proper healing.

\section{Acknowledgement}

The authors would like to thank Dr. Tan Ban Song and all the medical staff from the Orthopedic Department of Hospital Sultanah Nora Ismail Batu Pahat and the Ministry of Health Malaysia, for their help during data collection. Special thanks also go to the medical staff from the Medical Health Center, UTHM. We would also like to thank the Director General of Health, Ministry of Health, Malaysia for his permission to publish this article. This work is financially supported in part by the Ministry of Education Malaysia under grant FRGS vot number 1581 and University Tun Hussein Onn Malaysia under grant GPPS vot number U935. The authors have no conflict of interest to declare.

\section{References}

[1] Loewe, P., Stefanidis, I., Mertens, P.R., and Chatzikyrkou, C. 2016. Effects of Various Stages of Nephropathy on Wound Healing in Patients with Diabetes: An Observational Cohort Study Encompassing 731 Diabetics. International Urology and Nephrology. 48(5): 751-758.

DOI: https://doi.org/10.1007/s1 1255-016-1229-8

[2] Lazarus, G.S., Cooper, D.M., Knighton, D.R., Margolis, D.J., Pecoraro, R.E., Rodeheaver, G., and Robson, M.C. 1994. Definitions and Guidelines for Assessment of Wounds and Evaluation of Healing. Archives of Dermatology. 130(4): 489-493.

DOI: https://doi.org/10.1046/j.1524-475X.1994.20305.x

[3] Sungif, N.A.M., Zainudin, R., Ojep, D.N.A., and Rasit, A.H. 2015. Study of Wound Healing in Rats Treated with Skin of Poisonous Frog, Odorrana Hosii. Jurnal Teknologi. 77(25). DOI: https://doi.org/10.11113/jt.v77.6755 
[4] Anwar, U., and Bohari, S.P.M. 2019. Effect of Manihot Esculenta Aqueous Extract and Therapeutic Ultrasound In Accelerating the Wound Healing Process In Vitro. Jurnal Teknologi. 81(4). DOI: https://doi.org/10.11113/jt.v81.13135

[5] Holloway, S., Harding, K.G., Stechmiller, J., and Schultz, G. 2015. Acute and Chronic Wound Healing. In Wound Care Essentials - Practice Principles 4th Edition, Lippincott Williams and Wilkins. 82-98.

[6] Smigiel, K.S., and Parks, W.C. 2018. Macrophages, Wound Healing, and Fibrosis: Recent Insights. Current Rheumatology Reports. 20(4): 17.

DOI: https://doi.org/10.1007/s1 1926-018-0725-5

[7] Akula, S., Brosch, I.K., and Leipzig, N.D. 2017. Fluorinated Methacrylamide Chitosan Hydrogels Enhance Cellular Wound Healing Processes. Annals of Biomedical Engineering. 45(1 1): 2693-2702.

DOl: https://doi.org/10.1007/s10439-017-1893-6

[8] Philimon, S.P., Huong, A.K., and Ngu, X.T. 2015. Multispectral Imaging System for Quantitative Assessment of Transcutaneous Blood Oxygen Saturation. Jurnal Teknologi. 77(7).

DOI: https://doi.org/10.11113/jt.v77.6245

[9] Lindley, L.E., Stojadinovic, O., Pastar, I., and Tomic-Canic, M. 2016. Biology and Biomarkers for Wound Healing. Plastic And Reconstructive Surgery. 138(3): 185 DOI: 10.1097/PRS.0000000000002682

[10] Dissemond, J., Kröger, K., Storck, M., Risse, A., and Engels, P. 2015. Topical Oxygen Wound Therapies for Chronic Wounds: A Review. Journal of Wound Care. 24(2): 53-63. DOI: https://doi.org/10.12968/jowc.2015.24.2.53

[11] Bateman, S.D. 2015. Topical Haemoglobin Spray for Diabetic Foot Ulceration. British Journal of Nursing. 24. DOI: https://doi.org/10.12968/bjon.2015.24.Sup12.S24

[12] Park, C., Took, C.C., and Seong, J.-K. 2018. Machine Learning in Biomedical Engineering. Biomedical Engineering Letters. 8: 1-3.

DOI: https://doi.org/10.1007/s13534-018-0058-3

[13] Tamura, T. 2019. Current Progress of Photoplethysmography and SPO2 for Health Monitoring. Biomedical Engineering Letters. 9(1): 21-36. DOI: https://doi.org/10.1007/s13534-019-00097-w

[14] Chiang, N., Jain, J.K., Sleigh, J., and Vasudevan, T. 2017 Evaluation of Hyperspectral Imaging Technology in Patients With Peripheral Vascular Disease. Journal of Vascular Surgery. 66(4): 1192-1201.

DOI: https://doi.org/10.1016/j.jvs.2017.02.047

[15] Park, S., Jung, U., Lee, S., Lee, D., and Kim, C. 2017. Contrast-Enhanced Dual Mode Imaging: Photoacoustic Imaging Plus More. Biomedical Engineering Letters. 7(2): 121-133. DOI: https://doi.org/10.1007/s13534-016-0006-z

[16] Ganasala, P., and Kumar, V. 2014. Multimodality Medical Image Fusion Based On New Features In NSST Domain. Biomedical Engineering Letters. 4(4): 414-424. DOI: https://doi.org/10.1007/s13534-014-0161-z

[17] Saager, R.B., Sharif, A., Kelly, K.M., and Durkin, A.J. 2016. In Vivo Isolation of The Effects of Melanin from Underlying Hemodynamics Across Skin Types Using Spatial Frequency Domain Spectroscopy. Journal of Biomedical Optics. 21 (5): 057001. DOl: https://doi.org/10.1117/1.JBO.21.5.057001

[18] Rahim, I.M.A., Rahim, H.A., Ghazali, R., Ismail, R., and Omar, J. 2016. Glucose Detection in Blood Using NearInfrared Spectroscopy: Significant Wavelength for Glucose Detection. Jurnal Teknologi. 78: 7-4. DOI: https://doi.org/10.11113/jt.v78.9424
[19] Huong, A., Philimon, S., and Ngu, X. 2017. Multispectral Imaging Of Acute Wound Tissue Oxygenation. Journal of Innovative Optical Health Sciences. 10(03): 1750004. DOI: https://doi.org/10.1142/S1793545817500043

[20] Philimon, S.P., Huong, A.K., and Ngu, X.T. 2017. Investigation of Spatial Resolution Dependent Variability in Transcutaneous Oxygen Saturation Using Point Spectroscopy System. In IOP Conference Series: Materials Science and Engineering, IOP Publishing. 226(1): 012122. DOI:10.1088/1757-899X/226/1/012122

[21] Huong, A., and Ngu, X. 2014. The Application of Extended Modified Lambert Beer Model for Measurement of Blood Carboxyhemoglobin and Oxyhemoglobin Saturation. Journal of Innovative Optical Health Sciences. 7(03): 1450026 DOI: https://doi.org/10.1142/S1793545814500266

[22] Zijlstra, W.G., Buursma, A., and van Assendelft, O.W. 2000. Visible and Near Infrared Absorption Spectra Of Human and Animal Haemoglobin: Determination and Application. VSP.

[23] Kimmel, H.M., Grant, A., and Ditata, J. 2016. The Presence of Oxygen in Wound Healing. In Wounds: A Compendium Of Clinical Research And Practice. 28(8): 264-270.

[24] Cade, W.T. 2008. Diabetes-Related Microvascular and Macrovascular Diseases In The Physical Therapy Setting. Physical Therapy. 88(1 1): 1322-1335. DOI: https://doi.org/10.2522/ptj.20080008

[25] Chawla, A., Chawla, R., and Jaggi, S. 2016. Microvasular and Macrovascular Complications in Diabetes Mellitus: Distinct or Continuum?. Indian Journal of Endocrinology and Metabolism. 20(4): 546.

DOI: $10.4103 / 2230-8210.183480$

[26] Juhan, N., Khalid, Z.M., Zubairi, Y.Z., Zuhdi, A.S.M., and Ahmad, W.A.W. 2019. Risk Factors of Cardiovascular Disease Among ST-Elevation Myocardial Infarction Male Patients in Malaysia From 2006 To 2013. Jurnal Teknologi. $81(3)$.

DOI: https://doi.org/10.11113/jt.v81.12194

[27] Andersen, S.T., Witte, D.R., Fleischer, J., Andersen, H., Lauritzen, T., Jørgensen, M.E., Jensen, T.S., Pop-Busui, R., and Charles, M. 2018. Risk Factors for The Presence and Progression of Cardiovascular Autonomic Neuropathy in Type 2 Diabetes: ADDITION-Denmark. Diabetes Care. 41 (12): 2586-2594.

DOI: https://doi.org/10.2337/dc18-1411

[28] Lin, S.-P., Kung, H.-N., Tsai, Y.-S., Tseng, T.-N., Hsu, K.-D., and Cheng, K.-C. 2017. Novel Dextran Modified Bacterial Cellulose Hydrogel Accelerating Cutaneous Wound Healing. Cellulose. 24(1 1): 4927-4937. DOI: https://doi.org/10.1007/s10570-017-1448-x

[29] Philimon, S.P., Huong, A.K., Hafizah, W., Ong, P., and Ngu, X.T. 2016. Optical Investigation Of Variability In Body Region Dependent Transcutaneous Oxygen Saturation. In IOP Conference Series: Materials Science and Engineering. 012089

DOI: $10.1088 / 1757-899 \times / 160 / 1 / 012089$

[30] Kim, C.-K., Lee, S., Koh, D., and Kim, B.-M. 2011. Development of Wireless NIRS System with Dynamic Removal of Motion Artifacts. Biomedical Engineering Letters. 1 (4): 254-259. DOI: https://doi.org/10.1007/s13534-01 1-0042-7

[31] Vogel, A., Chernomordik, V.V., Demos, S.G., Pursley, R., Little, R.F., Tao, Y., Gandjbakhche, A.H., Yarchoan, R., Riley, J.D., and Hassan, M. 2007. Using Noninvasive Multispectral Imaging to Quantitatively Assess Tissue Vasculature. Journal of Biomedical Optics. 12(5): 051604051604-051613

DOI: https://doi.org/10.1117/1.2801718. 